\title{
Regulation of epidermal growth factor receptor synthesis by ovarian steroids in human endometrial cells in culture
}

\author{
H. Watson ${ }^{1}$, S. Franks ${ }^{2}$ and R. C. Bonney \\ ${ }^{1}$ Unit of Metabolic Medicine and ${ }^{2}$ Department of Obstetrics and Gynaecology. St Mary's Hospital \\ Medical School Imperial College of Science, Technology and Medicine, London W2 1PG, UK
}

\begin{abstract}
The aim of this study was to investigate the effect of oestradiol and progesterone on epidermal growth factor (EGF) binding in human endometrial glands and stromal cells in culture. Monolayers of isolated glands or stromal cells were cultured for 6 days in the presence or absence of steroids which were replenished daily. Binding of ${ }^{125}$ I-labelled EGF was measured in the presence and absence of unlabelled EGF. Over a 6 day period, oestradiol caused a dose-dependent increase in the number of EGF receptors in stromal cells, with a maximum effect of $150 \%$ control at a concentration of $10 \mathrm{nmol} \mathrm{l}^{-1}$. The effect of progesterone was also dose dependent and reached a maximum of $170 \%$ control at $100 \mathrm{nmol}$ progesterone $\mathrm{l}^{-1}$. Oestradiol and progesterone in combination caused a greater increase in EGF receptor concentration than did either steroid alone (control, $100 \pm 11 \%$; oestradiol, $144 \pm 11 \%$ control; progesterone, $200 \pm 20 \%$ control; oestradiol and progesterone, $288 \pm 6 \%$ control). Steroid treatment did not alter the affinity of the receptor for EGF. The stage of the cycle of the tissue did not affect the response to steroids. The effect of oestradiol was inhibited by the anti-oestrogen ICI182780, and that of progesterone by the anti-progestin RU486. In endometrial glands, neither oestradiol nor progesterone affected the number of EGF receptors, but the two steroids in combination induced an increase of $140 \pm 23 \%$ control where control was $100 \pm 15 \%$. These data demonstrate that oestradiol and progesterone increase the number of EGF receptors in vitro, and suggest that EGF is involved in mediating the actions of these steroids on the processes of proliferation and differentiation in the human endometrium.
\end{abstract}

\section{Introduction}

The human endometrium actively proliferates and differentiates under the influence of the steroid hormones oestrogen and progesterone. The mechanisms involved in these processes are poorly understood, but the role of growth factors as autocrine/ paracrine mediators of steroid hormone action on target tissues has been extensively investigated. One mechanism by which oestradiol is thought to exert its mitogenic effect on the uterus is by stimulating the synthesis of epidermal growth factor (EGF) (DiAugustine et al., 1988; Huet-Hudson et al., 1990) and its receptor (Mukku and Stancel, 1985; Lingham et al., 1988). Furthermore, cyclic variation in the concentration of the endometrial EGF receptor has been demonstrated in studies using tissue homogenates, suggesting that EGF receptor concentrations are regulated by ovarian steroids (Taketani and Mizuno, 1988; Troche et al., 1991).

In a study by Reynolds (1990), using separated human endometrial stromal cells and glands, treatment with oestradiol resulted in a decrease in the number of EGF receptors, while progesterone caused a small increase only in the glands. Progesterone has been shown to increase EGF binding and amounts of mRNA encoding EGF receptor in the T47D breast

Revised manuscript received 3 April 1996. cancer cell line (Murphy et al., 1985; Ewing et al., 1989) and Taketani and Mizuno (1991) have demonstrated an increase in EGF binding in mixed cultures of endometrial glands and stromal cells after treatment with progesterone for $24 \mathrm{~h}$.

We have previously characterized the EGF receptor in human glands and endometrial stromal cells cultured separately (Watson et al., 1994). The aim of this study was to use this system to investigate the effects of oestrogen and progesterone on EGF binding in the two types of endometrial cell.

\section{Materials and Methods}

\section{Materials}

Culture media, trypsin/EDTA, fetal calf serum and 'Linbro' multiwell plates were obtained from Flow Laboratories Ltd, Rickmansworth. All other reagents, unless otherwise stated, were obtained from the Sigma Chemical Co. Ltd (Poole). Hank's Balanced Salts Solution (HBSS) was always supplemented with $0.1 \mathrm{~g}$ kanamycin $\mathrm{l}^{-1}$ and 10 iu nystatin $\mathrm{ml}^{-1}$. Ham's F10 low phenol red culture medium (containing $1.2 \mathrm{mg}$ phenol red $\mathrm{l}^{-1}$ ) referred to below as Ham's F10 supplemented medium was, unless otherwise stated, supplemented with $5 \%$ $(\mathrm{v} / \mathrm{v})$ charcoal stripped fetal calf serum, $2 \mathrm{mmol}$ glutamine $^{-1}$, 
$5 \mathrm{mg}$ insulin $\mathrm{ml}^{-1}$ and $0.1 \mathrm{mg}$ kanamycin $\mathrm{ml}^{-1}$. Epidermal growth factor was obtained from Bachem Ltd (Saffron Walden). ${ }^{125}$ I-labelled EGF was prepared according to a method described by Watson et al. (1994). The antioestrogen ICI182780 was a gift from A. Wakeling, ICI, Macclesfield, and RU486 was obtained from Roussel Laboratories Ltd (Uxbridge).

\section{Collection of endometrium}

Endometrium was obtained in the operating theatre from women who were not on hormone therapy, but were undergoing hysterectomy for non-malignant conditions (menorrhagia, fibroids or prolapse). The informed consent of the patients was obtained. A portion of endometrium was sent to the histopathology laboratory for examination by light microscopy and endometrial dating and the remaining tissue to be used for culture studies was transported to the laboratory in HBSS in a sterile container on ice. Tissue from 24 women was used, 11 being in the proliferative phase and 13 in the secretory phase of the menstrual cycle. The study was approved by the local ethics committee (Parkside Health Authority).

\section{Preparation and treatment of cell cultures}

Stromal cells and intact glands were isolated by enzymatic dispersion with $0.125 \%(\mathrm{w} / \mathrm{v})$ collagenase (Type XI) (Bonney et al., 1991). Isolated stromal cells were plated directly into 24-well multiwell plates (well diameter $16 \mathrm{~mm}$ ) at a density of $2 \times 10^{5}$ cells per well, and glands were distributed evenly between half the number of wells required for stromal cells. Ham's F10 supplemented medium $(0.5 \mathrm{ml})$ containing steroid or vehicle (ethanol) alone was used. After $24 \mathrm{~h}$, when the stromal cells had attached to the surface of the well, blood cells and debris were removed by washing three times with Ham's FIO medium supplemented with kanamycin and nystatin. The cell cultures were maintained in Ham's F10 supplemented medium with steroid or ethanol for 5 days; the medium and treatments were replenished daily. On the sixth day, the cells were washed three times with Ham's F10 medium containing only kanamycin and nystatin and then incubated with steroid (or ethanol) for a further $24 \mathrm{~h}$ in Ham's F10 medium without serum but supplemented with $10 \mathrm{mmol}$ glutamine $\mathrm{l}^{-1}, 10 \mathrm{mg}$ insulin $\mathrm{ml}^{-1}$, $100 \mathrm{ng}$ hydrocortisone $\mathrm{ml}^{-1}, 10 \mathrm{mg}$ transferrin $\mathrm{ml}^{-\mathrm{I}}, 25 \mathrm{ng}$ sodium selenite $\mathrm{ml}^{-1}$ and $0.1 \mathrm{mg}$ kanamycin $\mathrm{ml}^{-\mathrm{I}}$

\section{Binding studies}

The method for measuring EGF receptor binding in human endometrial cells has been validated and described by Watson et al. (1994). Briefly, the cells were washed three times with $1 \mathrm{ml}$ of ice cold phosphate buffered saline (PBS), $\mathrm{pH} 7.5$, and then incubated at $37^{\circ} \mathrm{C}$ for $30 \mathrm{~min}$ in Ham's F10 medium containing $0.1 \%(w / v)$ BSA. Scatchard analysis (Scatchard, 1949) was carried out using a range of concentrations of ${ }^{125}$ [-labelled EGF of between 0.3 and $5.0 \mathrm{nmol}^{-1}$. Nonspecific binding was determined in the presence of a 500 -fold excess of unlabelled EGF. In single point assays, a saturating concentration of $5 \mathrm{nmol}^{125}$ I-labelled EGF $\mathrm{I}^{-1}$ was chosen, and
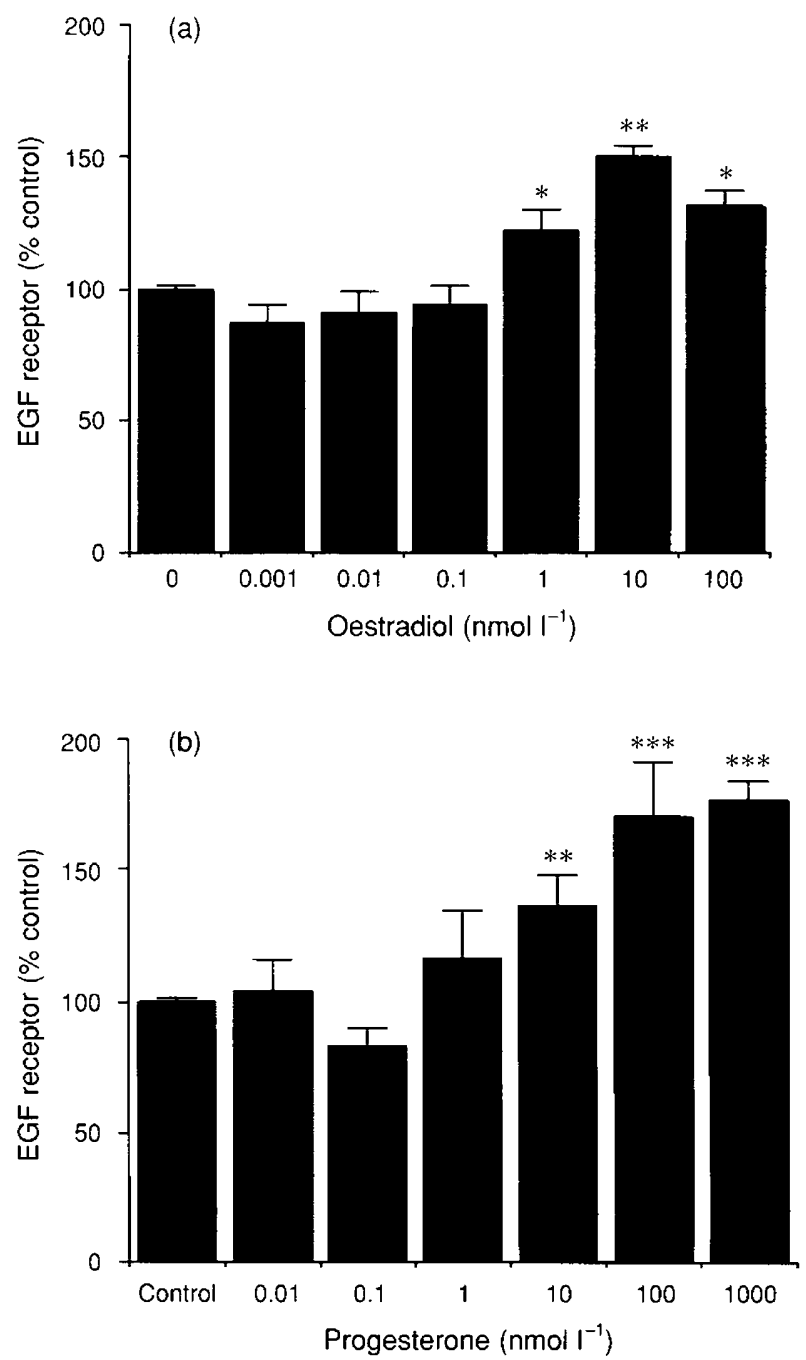

Fig. 1. The effect of treatment for 6 days with (a) oestradiol and (b) progesterone on epidermal growth factor (EGF) receptor concentrations in endometrial stromal cells. Each value represents the mean \pm SD of triplicate determinations. Results are expressed as fmol EGF bound $\mathrm{mg}^{-1}$ protein and then as percentage of control where the control value is designated as $100 \%$. This figure is typical of three experiments. Statistical analysis is by unpaired $t$ test $\left({ }^{*} P<0.05\right.$; $* * P<0.01 ; * * *<0.001$ compared with control).

measurements were made in triplicate. The reaction was terminated by the addition of $1 \mathrm{ml}$ ice-cold PBS and the cells then washed twice with $0.5 \mathrm{ml}$ of ice-cold PBS. The cells were solubilized with $5 \mathrm{~mol}$ sodium hydroxide $\mathrm{l}^{-1}(200 \mu \mathrm{l})$ and then transferred to polypropylene tubes and counted in a HewlettPackard $\gamma$ counter. Results were expressed as fmol EGF bound $\mathrm{mg}^{-1}$ protein. Protein concentrations were measured according to the method of Lowry et al. (1951).

\section{Results}

\section{Effect of oestradiol and progesterone}

The effect of oestradiol on the synthesis of EGF receptor by human endometrial stromal cells is shown (Fig. 1a). There was 
a dose-dependent increase in the number of EGF receptors over the concentration range $1-100 \mathrm{nmol}^{-1}$ with a maximum increase at $10 \mathrm{nmol} \mathrm{l}^{-1}$. At this concentration there was a $50 \%$ increase in the number of EGF receptors above the control value (which was designated to be $100 \%)(P<0.01)$. Treatment of tissue from 24 women, 11 being in the proliferative phase and 13 in the secretory phase of the menstrual cycle, with oestradiol $\left(1 \mathrm{nmol} 1^{-1}\right)$ showed a median (range) response of $150(120-200) \%$ control (proliferative phase; $n=11$ ) and 130 $(116-180) \%$ control (secretory phase; $n=11$ ). Two of 24 tissue preparations showed no response to oestradiol. Treatment with progesterone for 6 days also stimulated EGF receptor synthesis. The effect was significant at progesterone

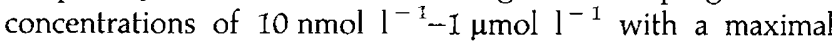
effect at a concentration of $1 \mu \mathrm{mol} \mathrm{I}{ }^{-1}$ (Fig. Ib). The median (range) response to progesterone was 191 (155-223) \% control $(n=6)$ in the proliferative phase and $164(143-195) \%$ control $(n=4)$ in the secretory phase. There was no difference in response to either oestradiol or progesterone between the two phases of the cycle. The variation in responses between different preparations can be expected in primary tissue culture systems. The two tissue preparations which did not respond to progesterone were also those which did not respond to oestradiol. Both were from the late secretory phase of the cycle.

\section{Effect of oestradiol and progesterone in combination}

In stromal cells, the two steroids in combination caused a greater increase in EGF receptor concentration than did either steroid alone (mean \pm SD: control, $100 \pm 7 \%$; 1 nmol oestradiol $1^{-1}, 144 \pm 11 \%$; $100 \mathrm{nmol}$ progesterone $\mathrm{l}^{-1}, 200 \pm 20 \%$; oestradiol and progesterone, $288 \pm 6 \%$ ) (Fig. 2a). The concentration of EGF receptor in the glandular epithelium was increased by oestradiol and progesterone in combination to $140 \pm 23 \%$ control but each steroid alone had no effect (Fig. 2b). The density at which the cells were initially plated did not affect the subsequent response to either oestradiol or progesterone (data not shown).

Time course of the stimulation of EGF receptor synthesis by oestradiol and progesterone

The stimulatory effect of steroid treatment on EGF receptor synthesis was significant at day 4 of treatment (mean $\pm \mathrm{SD}$ : control, $100 \pm 10 \%$; oestradiol, $142 \pm 18 \%, P<0.05$; progesterone, $142 \pm 24 \%, P<0.05$; oestradiol and progesterone, $171 \pm 23 \%, P<0.01$ ), was increased further on day 5, and on day 6 reached $169 \pm 27 \%$ (oestradiol) $P<0.01$; $203 \pm 24 \%$ (progesterone) $P<0.01 ; 311 \pm 67 \%$ (oestradiol and progesterone) $P<0.001$, where control was $100 \pm 7 \%$ (Fig. 3).

\section{Scatchard analysis}

Scatchard analysis of binding data (Fig. 4) revealed that steroid treatment increased the number of EGF receptors without changing the affinity of the receptor for EGF. The
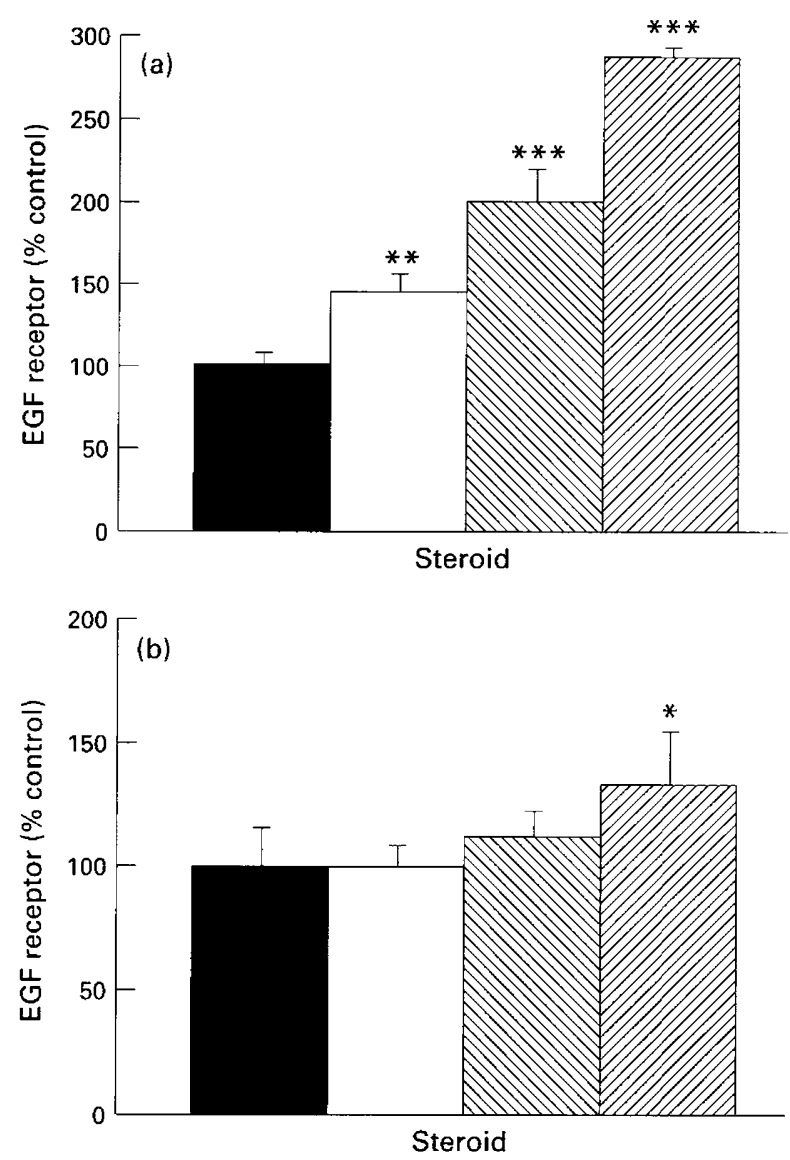

Fig. 2. The effect of a treatment for 6 days with $1 \mathrm{nmol}$ oestradiol $1^{-1}$ $(\square)$ and $100 \mathrm{nmol}$ progesterone $\mathrm{I}^{-1}(\mathbb{S})$, alone and in combination $(\nabla)$, on epidermal growth factor (EGF) receptor concentrations in (a) endometrial stromal cells and (b) endometrial glandular epithelium (control $\square$ ). Each value represents the mean $\pm s D$ of triplicate determinations. Results are expressed as fmol EGF bound $\mathrm{mg}^{-i}$ protein and then as percentage of control where the control value is designated as $100 \%$. This figure is typical of three experiments. Statistical analysis is by unpaired $t$ test $\left({ }^{*} P<0.05\right.$; ${ }^{* *} P<0.01$; $* * * P<0.001$ compared with control).

dissociation constant was $1.25 \mathrm{nmol}^{-1}$ for control, oestradiol, progesterone and combined oestradiol and progesterone treatment.

\section{Effect of ICI182780 and RU486 on the stimulation of EGF} receptor concentration by oestradiol and progesterone

The stimulatory effect of 1 nmol oestradiol $1^{-1}$ was reduced from $150 \pm 36 \%$ control to $112 \pm 12 \%$ control by the addition of the oestradiol antagonist ICI182780 (100 nmol $\left.1^{-1}\right)$. The progesterone antagonist RU486 $\left(1 \mu \mathrm{mol} \mathrm{l} \mathrm{l}^{-1}\right)$ caused a reduction in the basal EGF receptor concentration to $74 \pm 2 \%$ control and a small reduction in the effect of oestradiol to $124 \pm 6 \%$ control (Fig. 5). The effect of $100 \mathrm{nmol}$ progesterone $1^{-1}$ was unchanged by ICI 182780 , but completely abolished by RU486 (Fig. 6). ICI182780 did not significantly reduce the combined effect of oestradiol and progesterone, but RU486 


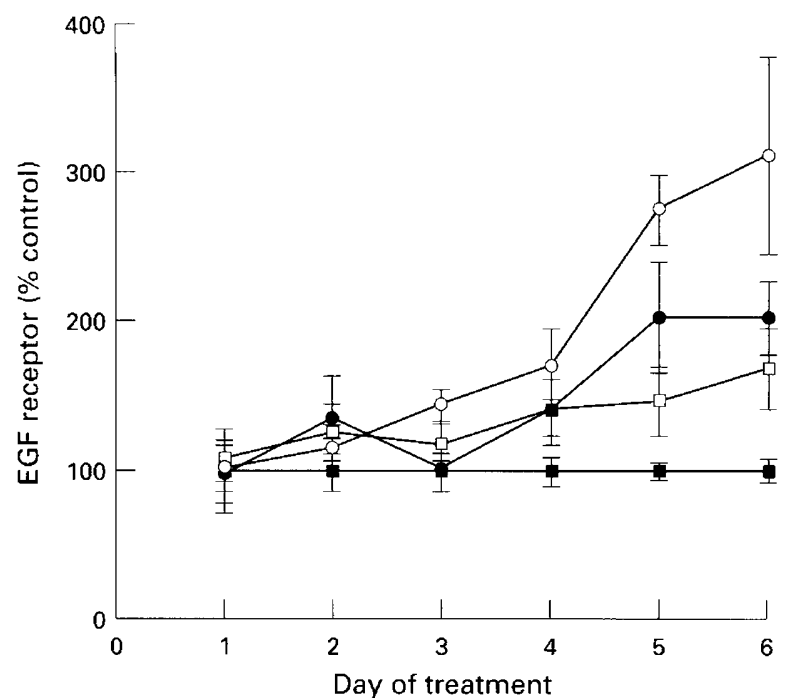

Fig. 3. Time course of induction of epidermal growth factor (EGF) receptor by $1 \mathrm{nmol}$ oestradiol $1^{-1}(\square)$ and $100 \mathrm{nmol}$ progesterone $1^{-1}(\boldsymbol{O})$ alone and $(\bigcirc)$ together (control $\boldsymbol{\square}$ ). Each value represents the mean $\pm \mathrm{sD}$ of triplicate determinations. Results are expressed as fmol EGF bound $\mathrm{mg}^{-1}$ protein and then as percentage of control where the control value is designated as $100 \%$. This figure is typical of three experiments.

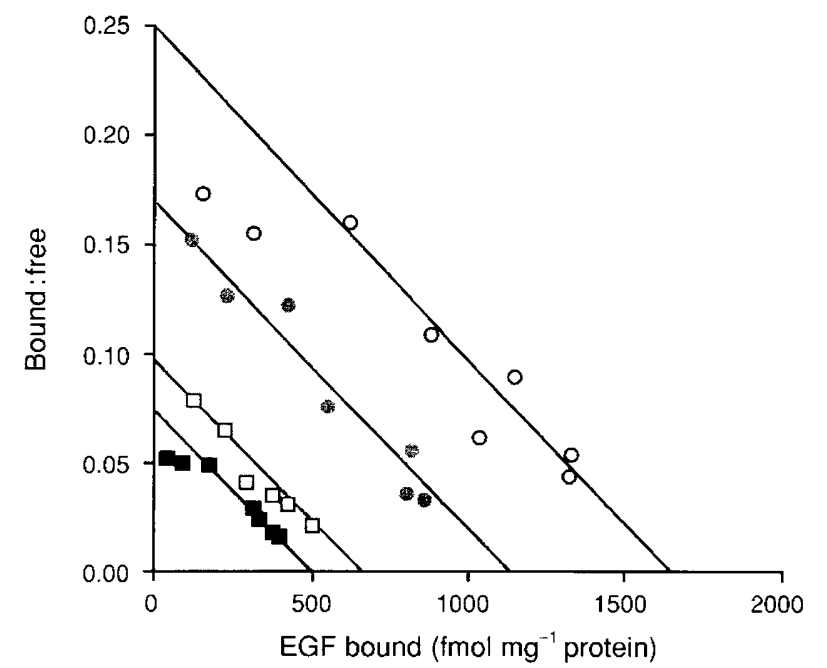

Fig. 4. Scatchard analysis of ${ }^{125}$ I-labelled epidermal growth factor (EGF) binding to endometrial stromal cells after treatment for ó days with $1 \mathrm{nmol}$ oestradiol $1^{-1}(\square)$ and $100 \mathrm{nmol}$ progesterone $\mathrm{l}^{-1}$

alone and $(\bigcirc)$ together (control $\mathbf{\square}$ ). This figure is typical of three experiments.

reduced the effect from $283 \pm 11 \%$ to $128 \pm 9 \%$ control; no further reduction was achieved by the two antagonists in combination (Fig. 7).

\section{Discussion}

The mechanisms involved in the action of oestrogen and progesterone on the growth and differentiation of the

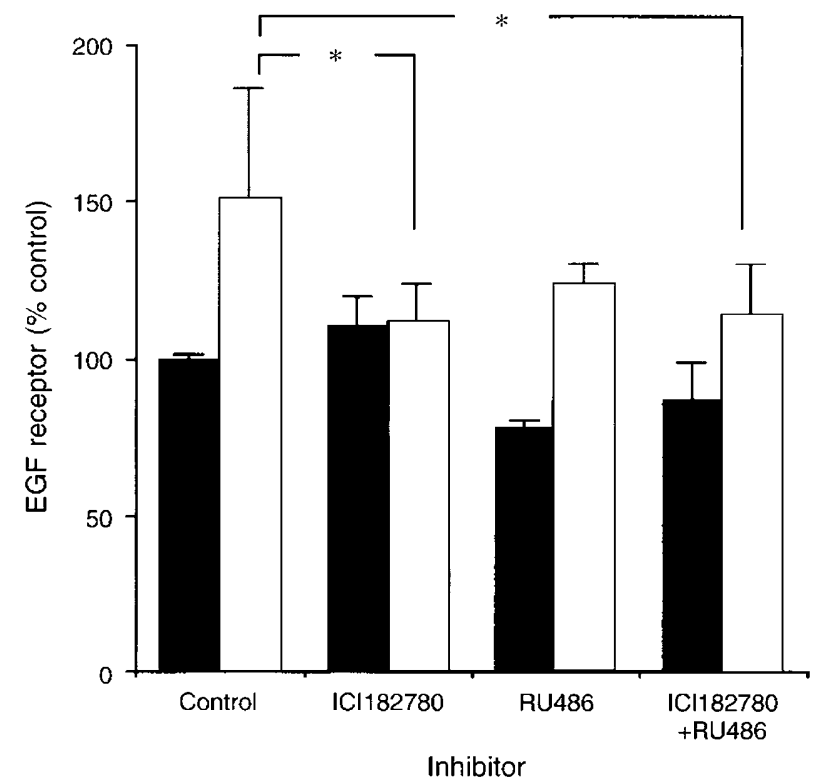

Fig. 5. The effect of $100 \mathrm{nmol}$ ICl182780 $\mathrm{l}^{-1}$ and $1 \mu \mathrm{mol}$ RU486 $\mathrm{l}^{-1}$ on the stimulation of epidermal growth factor (EGF) receptor synthesis with $(\square)$ and without $(\boldsymbol{\square}) 1 \mathrm{nmol}$ oestradiol $\mathrm{I}^{-1}$. Each value represents the mean $\pm S D$ of triplicate determinations. Results are expressed as $\mathrm{fmol}$ EGF bound $\mathrm{mg}^{-1}$ protein and then as percentage of control where the control value is designated as $100 \%$. This figure is typical of three experiments. Statistical analysis is by unpaired $t$ test $\left({ }^{*} P<0.05\right)$.

endometrium remain to be elucidated. Although the mitogenic action of oestrogen in vivo is well documented, attempts to reproduce these effects in vitro have produced variable results. Pavlik and Katzenellenbogen (1978) demonstrated an increase in proliferation of mixed cultures of human endometrium in response to oestradiol, but Haining et al. (1991a) were unable to reproduce this effect. The incorporation of $\left[{ }^{3} \mathrm{H}\right]$ leucine into protein, but not of $\left[{ }^{3} \mathrm{H}\right]$ thymidine into DNA, was stimulated by oestradiol in human endometrial stromal cells in a study by Mellor and Thomas (1995). Irwin et al. (1991) found no effect of oestradiol alone, but in combination with progesterone growth was stimulated.

The involvement of growth factors in the steroidal regulation of endometrial growth is now recognized. Chegini et al. (1992) and Hammond et al. (1993) demonstrated an increase in proliferation of human endometrial cells in response to EGF, although Haining et al. (1991a) found no effect of EGF alone. An increase in $\left[{ }^{3} \mathrm{H}\right]$ thymidine incorporation into DNA in endometrial stromal cells was induced in response to treatment with EGF (Mellor and Thomas, 1995). Our group have shown that EGF stimulates $\left[{ }^{3} \mathrm{H}\right]$ thymidine incorporation into endometrial stromal cells and that oestradiol increases the response to EGF twofold. Oestradiol alone has no effect (Bonney et al., 1991). Oestradiol stimulates the production of EGF in the immature mouse uterus (DiAugustine et al., 1988) and the synthesis of EGF receptor in the rat uterus (Mukku and Stancel, 1985). Furthermore, an increase in mRNA encoding EGF receptor has been noted after oestradiol treatment (Lingham et al., 1988). Taketani and Mizuno (1988) and Troche et al. (1991) found that EGF receptor concentrations in homogenates of human endometrium rise in the proliferative phase to reach 


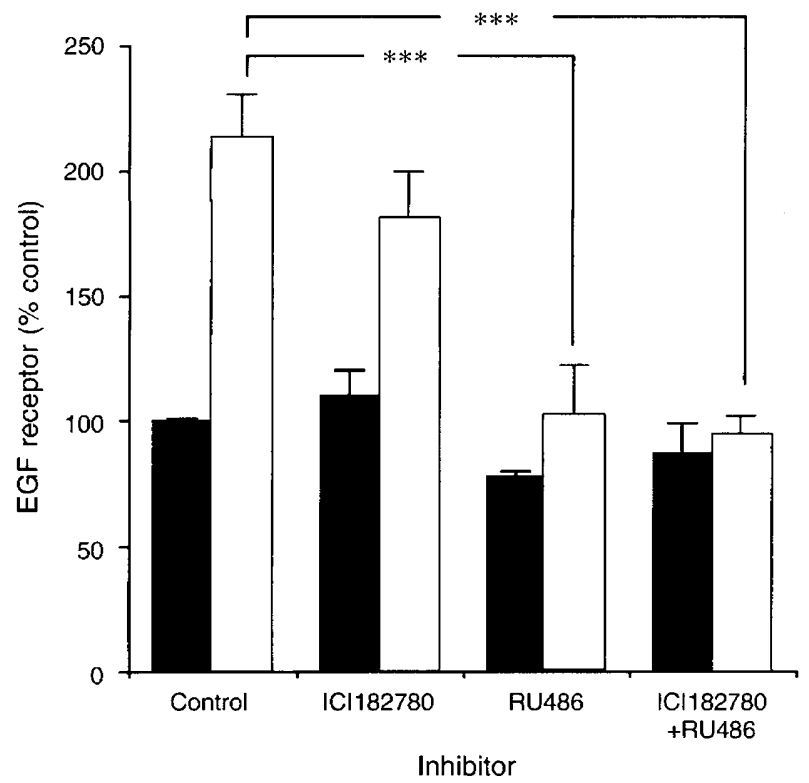

Fig. 6. The effect of $100 \mathrm{nmol}$ ICI182780 $\mathrm{l}^{-1}$ and I $\mu \mathrm{mol}$ RU486 $\mathrm{l}^{-1}$ on the stimulation of epidermal growth factor (EGF) receptor synthesis with $(\square)$ and without (ם) 100 nmol progesterone $l^{-1}$. Each value represents the mean \pm SD of triplicate determinations. Results are expressed as fmol EGF bound $\mathrm{mg}^{-1}$ protein and then as percentage of control where the control value is designated as $100 \%$. This figure is typical of three experiments. Statistical analysis is by unpaired $t$ test $(* * * P<0.001)$

a peak at mid-cycle then fall as the secretory phase progresses, suggesting that EGF receptor synthesis is regulated by oestradiol. However, Reynolds ef al. (1990) reported that oestradiol caused a decrease in EGF receptor in endometrial glands and stromal cell cultures, and that progesterone induced an increase in the glands. They suggest that the differences obtained in vivo and in vitro are a result of the lack of sophistication of the in vitro system in reproducing the in vivo situation. Alternatively, they propose that an autocrine feedback involving EGF and insulin like growth factor I, which are both upregulated by oestradiol, may be exerting a downregulatory effect on EGF receptor concentrations. In the present study, however, we have demonstrated a dose-dependent stimulation of EGF receptor synthesis by oestradiol after 4-6 days of treatment and a greater effect of progesterone. The two steroids in combination caused a synergistic stimulation. One would therefore expect EGF receptor concentrations in the endometrium to be highest in the mid-secretory phase rather than in the proliferative phase of the menstrual cycle. Taketani and Mizuno (1991) were unable to achieve an effect of oestradiol on mixed endometrial cultures after $I$ day of treatment but obtained a dose-dependent stimulation of EGF receptor concentration by progesterone which was enhanced by cortisol and oestradiol. They suggest that the concentration of progesterone is critical, as the effect they obtained using 100 nmol progesterone $\mathrm{I}^{-\mathrm{I}}$ (the concentration present in the plasma of women in the luteal phase) in combination with oestradiol was less than that using $0.1 \mathrm{nmol}$ progesterone $\mathrm{l}^{-1}$. In the present study, we have used only 1 nmol oestradiol $\mathrm{I}^{-1}$ in combination with $100 \mathrm{nmol}$ progesterone $\mathrm{I}^{-1}$; therefore, the

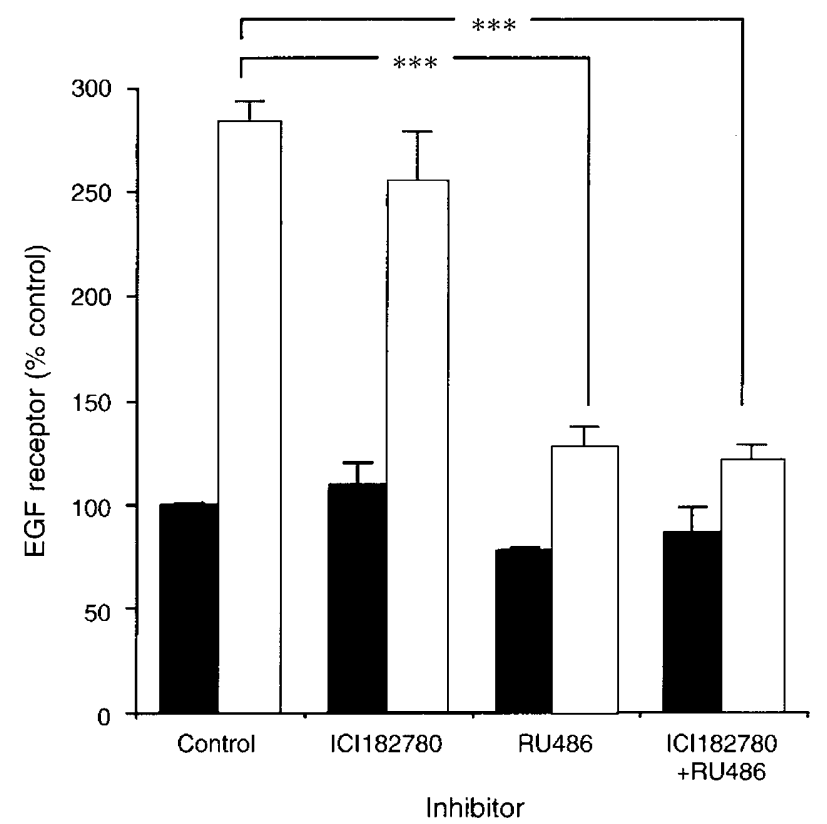

Fig. 7. The effect of $100 \mathrm{nmol}$ ICI182780 I-1 and I $\mu \mathrm{mol}$ RU486 $\mathrm{I}^{-1}$ on the stimulation of epidermal growth factor (EGF) receptor synthesis with $(\square)$ and without $(\boldsymbol{\square})$ oestradiol and progesterone in combination. Each value represents the mean \pm SD of triplicate determinations. Results are expressed as fmol EGF bound $\mathrm{mg}^{-\mathrm{I}}$ protein and then as percentage of control where the control value is designated as $100 \%$. This figure is typical of three experiments. Statistical analysis is by unpaired $t$ test $(* * * P<0.001)$.

different effects obtained using various concentrations were not investigated.

The combined effect of oestradiol and progesterone on EGF receptor synthesis is slightly greater than additive. This may be due to the induction of progesterone receptors by oestradiol, allowing an increase in the effect of progesterone (Milgrom et al., 1970, Eckert and Katzenellenbogen 1981). However, progesterone inhibits progesterone receptor synthesis, and antagonizes the increase in oestradiol receptor synthesis induced by oestradiol (Milgrom et al., 1973; Tseng and Gurpide, 1975). This reduction in steroid hormone receptor concentrations would be expected to reduce the overall effect of oestrogen and progesterone on EGF receptor synthesis. The steroids may therefore be controlling the magnitude of the combined response by a complex regulation of the concentration of their own and each other's receptors.

Although ICI182780 reduced the stimulation of EGF receptor synthesis by oestradiol, there was no significant reduction of the combined oestradiol and progesterone effect. The stimulation of EGF receptor synthesis by oestradiol is small compared with that achieved by progesterone, and the inhibition by ICI 182480 is therefore relatively slight. This effect may be overcome in the presence of the more potent stimulator progesterone, the overall result being a small but not significant inhibitory effect of ICI182780 on the combined oestrogen and progesterone stimulated response. RU486 did not affect the number of cells as assessed by either protein or DNA concentrations, although EGF receptor concentration was reduced. Bardon ef al. (1987) proposed that one of the 
mechanisms by which progesterone antagonists inhibit growth of breast tumour cells is via 'progesterone receptor-mediated cytostatic effects'. These effects are characterized by inhibition of the growth-stimulatory actions of unrelated (nonprogestin) growth factors. The reduction of EGF receptor concentration by RU486 may therefore contribute to its cytostatic effects by inhibiting EGF action.

Since, in vivo, progesterone has a gradual anti-proliferative effect on endometrial stromal cells, except those adjacent to the spiral arterioles, and on the glandular epithelium of the functionalis layer, it may be expected that the synthesis of a growth factor or its receptor that mediated endometrial growth would be inhibited by progesterone. Norqvist (1970) and Neulen et al. (1987) reported an inhibition of $\left[{ }^{3} \mathrm{H}\right]$ thymidine incorporation after treatment of human endometrial cells with progesterone. However, Irwin et al. (1989) demonstrated that progesterone caused a continued proliferation of human endometrial stromal cells in culture, and that oestradiol further stimulated cell growth when combined with progesterone but had no effect alone. Moreover, the production of prolactin, laminin and fibronectin, indicators of decidualization, were induced by progesterone, and enhanced by the addition of oestradiol. They suggest that exposure of stromal cells to physiological concentrations of oestradiol and progesterone in vitro induces decidualization, with the concomitant increase in proliferation. In further studies, Irwin et al. (1991) demonstrated that the proliferative effects of EGF were dependent on the presence of progesterone in the culture medium. Moreover, EGF and progesterone in combination induced decidualization of endometrial cells, as indicated by the production of prolactin, laminin and fibronectin. The increase in EGF receptor concentrations after treatment with progesterone, and oestradial and progesterone in combination in our studies, may reflect the mediation by EGF of the processes of differentiation and predecidualization in the early luteal phase in preparation for implantation. The importance of EGF in this process is suggested by the presence of increased EGF receptors at the pre-implantation sites of mouse uteri (Brown et al., 1989). Although the results of their study do not identify which cell types are responsible for the increased EGF binding, the authors speculate that the endometrial stromal and epithelial cells may be responsible for the majority of the increase, since the endometrium proliferates extensively during and after implantation, and mouse uterine epithelial cells in culture express relatively high amounts of specific, high-affinity EGF receptors (Tomooka et al., 1986). Indeed, EGF initiated implantation of embryos transferred into the uteri of progesterone primed hypophysectomized rats (Johnson and Chatterjee, 1993). Chakraborty et al. (1988) suggest that the gradual rise in EGF binding in the uterus which was observed with the advancement of pregnancy in rats may be due to the interaction between progesterone and oestrogen. mRNA encoding EGF was not detected in normal human endometrium by Sakakibara et al. (1994), possibly owing to its low copy number, since reverse transcriptase polymerase chain reaction revealed the expression of mRNA encoding EGF in human endometrium in a study by Haining et al. (1991b). However, Sakakibara et al. (1994) suggest that the increase in EGF gene expression which they observed during the decidualization process was regulated by progesterone, and that EGF could be involved in progesterone mediated uterine decidual cell growth. Sumida and Pasqualini (1989) found that, although the stimulation of progesterone receptors by EGF was inhibited by antioestrogens, the mitogenic effect of EGF was unaffected. They suggested that the regulation of cell proliferation and of the progesterone receptor are two separate parameters of EGF action. Moreover, Mellor and Thomas (1995) demonstrated that the EGF receptor antibody ICRI6 and ICI182780 blocked EGF-mediated proliferation but not EGF-induced protein synthesis, suggesting that various different signal transduction pathways of EGF action are used in the endometrium. The interaction between progesterone, EGF and their receptors in the human endometrium may therefore be concerned with differentiation and decidualization rather than the mechanism of cell proliferation.

The poor response of the endometrial glandular preparations may be due to the morphological changes that occur in this cell type in culture. Kirk et al. (1978) noted that glandular epithelial cells cultured on plastic had a flattened, fusiform appearance with loss of surface microvilli. Marshburn ef al. (1992) suggest that this loss of polarized morphological features may alter the responses of endometrial epithelial cells to hormonal treatment. The small response may be due to contaminating stromal cells, as immunocytochemical staining of the glandular cultures using antibody to cytokeratin, an epithelial cell-specific cytoskeletal marker, has confirmed that the glandular cultures are only approximately $90 \%$ pure. Vimentin staining of the stromal cell cultures has demonstrated that their purity is approximately $90 \%$. These findings are in agreement with those of other groups who used similar separation procedures (Chegini et al., 1992; Hammond et al., 1993).

The stimulation of EGF receptor synthesis by oestradiol and progesterone in human endometrial stromal cells suggests that EGF mediates the effects of these steroids in this target tissue. The effects of EGF may be partially mediated by the oestrogen receptor (Ignar-Trowbridge et al., 1992; Mellor and Thomas, 1995) and EGF in turn increases oestrogen and progesterone receptors (Sumida et al., 1988). Therefore, the findings of the present study may represent part of a paracrine loop involving cross-talk between the signalling pathways of a polypeptide growth factor and steroid hormones. The mitogenic effect of oestradiol in the proliferative phase and the stimulation of differentiation and decidualization by progesterone in the luteal phase may be regulated by EGF, resulting in an endometrium that is receptive to implantation.

The authors gratefully acknowledge the assistance of the operating theatre staff of the Samaritan Hospital for Women, London, in the collection of endometrial tissue. This work was supported by the Wellcome Trust, the Band Trust and the Joint Standing Research Committee, St Mary's Hospital, London.

\section{References}

Bardon S, Vignon F, Montcouttier P and Rochefort H (1987) Steroid receptormediated cytotoxicity of an antiestrogen and an antiprogestin in breast cancer cells Cancer Research 47 1441-1448

Bonney RC, Beesley JS and Franks S (1990) Effect of epidermal growth factor (EGF) and oestradiol ( $\left.E_{2}\right)$ on the proliferation of human endometrial cells in culture Journal of Steroid Biochemistry 36 (Supplement), Abstract 199 
Bonney RC, Beesley JS and Franks S (1991) Release of arachidonic acid from human endometrial cells in culture mediated by calcium ionophore (A23187) or fluoride Journal of Reproduction and Fertility 93, 449-460

Brown MJ, Zogg JL, Schultz GS and Hilton FK (1989) Increased binding of epidermal growth factor at preimplantation sites in mouse uteri Endocrinology 124 2282-2888

Chakraborty C, Tawfik OW and Dey SK (1988) Epidermal growth factor binding in rat uterus during the peri-implantation period Biochemical and Biophysical Research Communications 153 564-569

Chegini N, Rossi MJ and Masterson BJ (1992) Platelet derived growth factor (PDGF), epidermal growth factor (EGF), and EGF and PDGF $\beta$ receptors in human endometrial tissue: localisation and in vitro action Endocrinology 130 2373-2385

DiAugustine RP, Petrusz P, Bell GI, Brown CF, Korach KS, McLachlan JA and Teng CT (1988) Influence of oestrogen on mouse uterine epidermal growth factor precursor protein and messenger ribonucleic acid Endocrinology 122 23552363

Eckert RL and Katzenellenbogen BS (1981) Human endometrial cells in primary tissue culture: modulation of progesterone receptor level by natural and synthetic estrogens in vitro Journal of Endocrinology and Metabolism 52 $699-708$

Ewing TM, Murphy LJ, Ng MC, Pang GY, Lee CS, Watts CK and Sutherland RL (1989) Regulation of epidermal growth factor receptor by progestins and glucocorticoids in human breast cancer cell lines International journal of Cancer 44 744-752

Haining REB, Cameron IT, van Papendorp C, Davenport AP, Prentice A, Thomas EJ and Smith SK (1991a) Epidermal growth factor in human endometrium: proliferative effects in culture and immunocytochemical localisation in normal and endometriotic tissues Human Reproduction 6 1200-1205

Haining REB, Schufield JP, Jones DSC, Rajput-Williams J and Smith SK (1991b) Identification of mRNA for epidermal growth factor, transforming growth factor- $\alpha$ present in low copy number in human endometrium and decidua using reverse transcriptase-polymerase chain reaction Molecular Endocrinology $6207-214$

Hammond MG, Oh S-T, Anners J, Surrey ES and Halme J (1993) The effect of growth factors on the proliferation of endometrial cells in culture American Journal of Obstetrics and Gynaecology 168 1131-1138

Huet-Hudson YM, Chacraborty L, De SK, Suzuki Y, Andrews GK and Dey SK (1990) Estrogen regulates the synthesis of epidermal growth factor in mouse uterine epithelial cells Molecular Endocrinology 4 510-523

Ignar-Trowbridge DM, Nelson KG, Bidwell MC, Curtis SW, Washburn TF, McLaughlin JA and Korach KS (1992) Coupling of dual signalling pathways: epidermal growth factor action involves the estrogen receptor Proceedings of the National Academy of Sciences, USA 89 4658-4662

Irwin JC, Kirk D, King RJB, Quigley MM and Gwatkin RBL (1989) Hormonal regulation of human endometrial stromal cells in culture: an in vitro model for decidualisation Fertility and Sterility 52 761-768

Irwin JC, Utian WH and Eckert RL (1991) Sex steroids and growth factors differentially regulate the growth and differentiation of cultured human endometrial stromal cells Endocrinology 129 2385-2392

Johnson DC and Chatterjee S (1993) Embryo implantation in the rat uterus induced by epidermal growth factor Journal of Reproduction and Fertility 99 $557-559$

Kirk D, King RJB, Heyes J, Peachey L, Hirsch PJ and Taylor RWT (1978) Normal human endometrium in cell culture In Vitro 14 651-662

Lingham RB, Stancel GM and Loose-Mitchell DS (1988) Estrogen regulation of epidermal growth factor messenger ribonucleic acid Molecular Endocrinology $2230-235$

Lowry OH, Rosebrough NJ, Farr AL and Randal RJ (1951) Protein measurement with the Folin phenol reagent Journal of Biological Chemistry 193 263-275

Marshburn PB, Head JR, MacDonald PC and Linette Casey M (1992) Culture characteristics of human endometrial glandular epithelium throughout the menstrual cycle: modulation of deoxyribonucleic acid synthesis by $17 \beta$ estradiol and medroxyprogesterone acetate American Journal of Obstetrics and Gynaecology 167 1888-1898

Mellor SJ and Thomas EJ (1995) Interactions between oestradiol and epidermal growth factor in endometrial cell proliferation and differentiation Journal of Reproduction and Fertility $104 \quad 157-164$

Milgrom E, Thi L, Atger M and Baulieu EE (1970) Progesterone in uterus and plasma. IV Progesterone receptor(s) in guinea pig uterus cytosol Steroids 16 741-754

Milgrom E, Thi L, Atger M and Baulieu EE (1973) Mechanisms regulating the concentration and conformation of progesterone receptor(s) in the uterus Journal of Biological Chemistry 248 6366-6474

Mukku VR and Stancel GM (1985) Regulation of epidermal growth factor receptor by estrogen Joumal of Biological Chemistry $2609820-9824$

Murphy LJ, Sutherland RL and Lazaus L (1985) Regulation of growth hormone and epidermal growth factor receptors by progestins in breast cancer cells Biochemical and Biophysical Research Communications 131 767-773

Neulen J, Wagner B, Runge M and Breckwoldt M (1987) Effect of progestins, androgens, estrogens and antiestrogens on ${ }^{3} \mathrm{H}$-thymidine uptake by human endometrial and endosalpinx cells in vitro Archives of Gynaecology $\mathbf{2 4 0}$ 225-232

Norquist S (1970) The synthesis of DNA and RNA in normal human endometrium in short-term incubation in vitro and its response to oestradiol and progesterone Journal of Endocrinology 48 17-28

Pavlik EJ and Katzenellenbogen BS (1978) Human endometrial cells in primary tissue culture: estrogen interactions and modulation of cell proliferation Journal of Clinical Endocrinology and Metabolism 47 333-334

Reynolds RK, Talavera F, Roberts JA, Hopkins MP and Menon KMJ (1990) Regulation of epidermal growth factor and insulin-like growth factor I receptors by estradiol and progesterone in normal and neoplastic endometrial cell cultures Gynaecologic Oncology 38 396-406

Sakakibara H, Taga M, Saji M, Kida H and Minaguchi H (1994) Gene expression of epidermal growth factor in human endometrium during decidualisation Journal of Clinical Endocrinology and Metabolism 79 223-226

Scatchard G (1949) The attraction of proteins for small molecules and ions Annals of the New York Academy of Sciences 51 660-672

Sumida C and Pasqualini JR (1989) Antioestrogens antagonise the stimulatory effect of epidermal growth factor on the induction of progesterone receptor in fetal uterine cells in culture Endocrinology 124 591-597

Sumida C, Lecerf F and Pasqualini JR (1988) Control of progesterone receptors in fetal uterine cells in culture: effects of estradiol, progestins, antioestrogens and growth factors Endocrinology 122 3-11

Taketani Y and Mizuno M (1988) Cyclical changes in epidermal growth factor receptor in human endometrium during the menstrual cycle Endocrinologica Japonica 35 19-25

Taketani Y and Mizuno M (1991) Evidence for direct regulation of epidermal growth factor receptors by steroid hormones in human endometrial cells Human Reproduction 6 1365-1369

Tomooka Y, DiAugustine RP and MacLachan JA (1986) Proliferation of mouse uterine epithelial cells in vitro Endocrinology 118 1011-1018

Troche V, O'Connor DM and Schaudies RP (1991) Measurement of human epidermal growth factor receptor in the endometrium during the menstrual cycle American Journal of Obstetrics and Gynaecology 1651499 1503

Tseng L and Gurpide E (1975) Effect of progestins on estradiol receptor levels in human endometrium Journal of Clinical Endocrinology and Metabolism 41 402-404

Watson H, Bonney RC and Franks S (1994) Characterization of epidermal growth factor receptor in human endometrial stromal cells in culture Journal of Reproduction and Fertility $101415-420$ 